\title{
Kadar Sucam-1 pada Penderita Sindrom Nefrotik Kambuh
}

Nanan Sekarwana

Bagian Ilmu Kesehatan Anak, Fakultas Kedokteran Universitas Padjadjaran, RSUP dr. Hasan Sadikin, Bandung

Latar belakang. Sindrom nefrotik pada anak umumnya sensitif terhadap pengobatan, walaupun demikian 60\%-80\% akan mengalami kekambuhan; 20\% jenis kambuh jarang, 40\% jenis kambuh sering. Prognosis pada sindrom nefrotik kambuh sering kurang baik dikaitkan dengan peningkatan kadar profil lemak kecuali HDL. Untuk petanda aterosklerosis dapat digunakan kadar VCAM-1 dalam serum. Dengan meningkatnya kadar profil lemak pada anak dengan sindrom nefrotik, muncul pertanyaan apakah anak dengan sindrom nefrotik juga memiliki risiko menderita aterosklerosis.

Tujuan. Mengetahui kadar sVCAM-1 pada sindrom nefrotik kambuh sering dibandingkan dengan sindrom nefrotik kambuh jarang dan anak sehat.

Metode. Penelitian menggunakan pendekatan cross-sectional yang dilakukan pada 29 anak dengan sindrom nefrotik kambuh jarang, 21 anak dengan sindrom nefrotik kambuh sering dan 50 anak sehat.

Hasil. Rerata sVCAM-1 masing-masing pada sindrom nefrotik jenis kambuh sering, kambuh jarang dan kontrol 871,01; 1038,31 dan 715,30 ng/dl.

Kesimpulan. Terdapat perbedaan kadar sVCAM yang bermakna pada ketiga kelompok $(\mathrm{F}=22,43$; p. $<0,001)$. Jenis sindrom nefrotik, baik kambuh sering maupun kambuh jarang, tidak mempunyai kontribusi yang besar terhadap kadar sVCAM-1 (adjusted $R^{2} 8,9 \%$ ), walaupun diketahui bahwa prognosis sindrom nefrotik kambuh sering lebih buruk dibandingkan dengan kambuh jarang karena adanya faktor risiko aterosklerosis yang berulang. (Sari Pediatri 2007; 9(3):163-166).

Kata kunci: aterosklerosis, petanda, anak, sindrom nefrotik

\footnotetext{
Alamat korespondensi

DR. dr. Nanan Sekarwana, SpA(K), MARS. Bagian Ilmu Kesehatan Anak Fakultas Kedokteran Universitas Padjadjaran

Jl. Pasteur 38 Bandung 40161 Tlp/Fax. 022-2034426
}

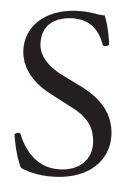

indrom nefrotik (SN) adalah kelainan glomerular yang sering terjadi pada anak, ditandai adanya edema, proteinuria, hipoalbuminemia, disertai hiperlipidemia atau hiperkolesterolemia pada sebagian besar pasien. ${ }^{1-4}$ Berdasarkan penelitian di berbagai negara, didapatkan insidensi sebesar 2-4 kasus setiap 100.000 populasi per tahun, sebagian besar berusia 3 tahun. ${ }^{5}$ Di Bagian Ilmu 
Kesehatan Anak FK UNPAD/RSHS telah dirawat 129 $(53,5 \%)$ pasien sindrom nefrotik dari 241 kasus seluruh penyakit ginjal, antara Januari 1995 hingga Juni 1999, rerata usia 6 tahun 4 bulan. ${ }^{6}$

Pasien SN dapat mengalami kekambuhan yang terbagi menjadi kambuh sering dan kambuh jarang. Keadaan kekambuhan dikaitkan dengan episode serangan kekambuhan berdasarkan waktu tertentu setelah terjadinya remisi. Kambuh jarang didefinisikan apabila kambuh $<2$ kali dalam 6 bulan sejak respons awal atau $<4$ kali dalam periode 1 tahun. Kambuh sering didefinisikan apabila kambuh $>2$ episode dalam 6 bulan sejak respons awal atau $>4$ kali dalam periode 1 tahun. Episode kambuh ini menjadi sangat penting berkaitan dengan pengelolaan dan prognosis $\mathrm{SN} .^{1}$

Seperti halnya pada orang dewasa, profil lemak SN anak secara karakteristik ditandai dengan meningkatkan kolesterol total, trigliserida, very low density lipoprotein (VLDL), low density lipoprotein (LDL), dan lipoprotein a, juga dapat disertai konsentrasi high density lipoprotein (HDL) yang normal atau menurun. ${ }^{6}$ Berdasarkan beberapa penelitian terakhir, hiperlipidemia atau hiperkolesterolemia diyakini merupakan faktor risiko potensial untuk terjadinya aterosklerosis ataupun terjadinya penyakit jantung koroner. ${ }^{7}$

Beberapa hasil penelitian melaporkan bahwa proses aterosklerosis dapat diprediksi melalui pemeriksaan kadar sVCAM-1 dalam plasma. Menurut Peter dkk, sVCAM-1 merupakan prediktor kuat serta optimal dan mampu memberikan gambaran mengenai perluasan aterosklerosis pada orang dewasa. Kadar protein VCAM1 yang dilepaskan di sirkulasi sebanding dengan konsentrasi sVCAM-1, sehingga dapat digunakan sebagai petanda adanya proses aterosklerosis dan dapat menunjukkan derajat keparahan aterosklerosis. ${ }^{9}$ Namun demikian terdapat beberapa hal yang mempengaruhi ekspresi sVCAM-1, antara lain inflamasi akut pada infeksi atau adanya jejas pada jaringan. ${ }^{10}$
Penelitian ini bertujuan memperlihatkan gambaran sVCAM-1 pada anak yang menderita sindrom nefrotik kambuh.

\section{Metode}

Subjek penelitian adalah anak penderita SN kambuh dengan rentang usia 24-168 bulan dengan status gizi baik, yang datang ke Klinik Ginjal Bagian Ilmu Kesehatan Anak FK Unpad/RSHS dan FK UI/RSCM dari bulan Juli 2001-November 2003.

Kriteria eksklusi adalah subjek dengan hipertensi, diabetes mellitus, infeksi kronis (PPD test positif dengan indurasi $15 \mathrm{~mm}$ ), infeksi akut (C Reactive Protein/CRP $>10 \mathrm{mg} / \mathrm{L}$ ), merokok (keterangan diperoleh dari anamnesa), serta terdapat satu dari kriteria: hematuria makroskopis atau mikroskopis ( $>5$ eritrosit/LPB), kultur urine positif (koloni urin pancar tengah $10^{5} / \mathrm{ml}$ ), penurunan fungsi ginjal (kadar ureum $>40 \mathrm{mg} / \mathrm{dl}$ dan atau kreatinin $>1 \mathrm{mg} / \mathrm{dl})$, serta anemia $(\mathrm{Hb}<9 \mathrm{gL})$

Kelompok kontrol adalah anak sehat usia 24-168 bulan yang datang ke Klinik Tumbuh Kembang Bagian Ilmu Kesehatan Anak FK Unpad/RSHS dan FK UI/ RSCM dari bulan Juli 2001-November 2003 dan orang tua/wali sudah mendapatkan informed consent dan menyetujui untuk berpartisipasi dalam penelitian ini.

Desain penelitian cross sectional yang menggambarkan profil sVCAM-1 pada pasien SN. Analisis statistik yang digunakan ANOVA dan regresi linier.

\section{Hasil}

Subjek terdiri atas 53 anak, 47 dari RSHS dan 6 dari RSCM Jakarta. Lima puluh dari 53 pasien yang memenuhi kriteria inklusi terdiri atas 21 SN kambuh sering dan 29 SN kambuh jarang. Tiga subjek, 1 dari

Tabel 1. Distribusi menurut umur dan jenis kelamin

\begin{tabular}{lcccc}
\hline Karakteristik & $\begin{array}{c}\text { SN kambuh } \\
\text { sering }(\mathrm{n}=21)\end{array}$ & $\begin{array}{c}\text { SN kambuh } \\
\text { jarang }(\mathrm{n}=29)\end{array}$ & $\begin{array}{c}\text { Kelompok kontrol } \\
(\mathrm{n}=50)\end{array}$ & $\mathrm{p}$ \\
\hline $\begin{array}{l}\text { Umur (bulan) }(X \pm \mathrm{SB}) \\
\text { Jenis kelamin }(\%)\end{array}$ & $87,4 \pm 38,3$ & 93,7 & 78,8 & ${ }^{*} \mathrm{p}>0,05$ \\
- Laki-laki & $17(81)$ & $17(58.6)$ & $34(68)$ & \\
- Perempuan & $4(19)$ & $12(41.4)$ & $16(32,0)$ & \\
\hline
\end{tabular}

Keterangan:*one way ANOVA ** Chi square test 
Nanan Sekarwana: Kadar Svcam-1 pada Sindrom Nefrotik Kambuh

Tabel 2. Titer sVCAM-1

\begin{tabular}{ccccc}
\hline $\begin{array}{c}\text { sVCAM-1 } \\
(\mathrm{n}=21)\end{array}$ & $\begin{array}{c}\text { SN kambuh sering } \\
(\mathrm{n}=29)\end{array}$ & $\begin{array}{c}\text { SN kambuh jarang } \\
(\mathrm{n}=50)\end{array}$ & Kelompok kontrol & Signifikansi \\
\hline$(\bar{X} \pm$ SB $)$ & $871,01 \pm 347,39$ & $1038,31 \pm 263,83$ & $715,30 \pm 176,90$ & $\mathrm{p}<0,001^{*}$ \\
Rentang & $461-1773$ & $479,20-1574,50$ & $436-1267,50$ & \\
\hline
\end{tabular}

Keterangan: *One Way ANOVA

Tabel 3. Analisis regresi linier titer sVCAM

\begin{tabular}{lccc}
\hline Variabel & $\beta$ & signifikansi & Adjusted $\mathrm{R}^{2}$ \\
\hline Konstanta & 763,008 & 0,00 & \\
Jenis kambuh & 110,798 & 0,002 & 0,089 \\
\hline
\end{tabular}

SN kambuh sering dan 2 dari SN kambuh jarang tidak melanjutkan penelitian karena hasil laboratoriumnya termasuk pada outlier.

Bila dibandingkan menurut umur dan jenis kelamin terdapat persamaan karakteristik antara ketiga grup ( $p>0,05)$ sebagaimana tertera pada Tabel 1 .

Kadar titer sVCAM-1 dari ketiga kelompok tertera pada Tabel 2.

Pada Tabel 3 tertera hasil analisis regresi linier yang menunjukkan bahwa jenis Sindrom Nefrotik memberikan kontribusi yang rendah pada nilai titer sVCAM (adjusted $\mathrm{R}^{2}:$ 8,9\%).

\section{Diskusi}

Kadar lemak tinggi dalam darah akan menyebabkan risiko terjadi aterosklerosis dan glomerulonefritis. ${ }^{11}$ Hiperlipidemia atau hiperkolesterolemia telah dilaporkan sebagai faktor risiko yang potensial untuk terjadi aterosklerosis dan penyakit jantung koroner. ${ }^{12}$ Silva JMP ${ }^{13}$ melaporkan kejadian infark miokard akut pada anak berumur 7 tahun yang diketahui menderita SN dengan kambuh sering, diduga penyebabnya karena hiperlipidemia. ${ }^{13}$

Pada beberapa penelitian baik secara invivo maupun invitro, hiperlipidemia dapat meningkatkan ekspresi molekul adhesi dan VCAM-1, yaitu salah satu superfamili dari kelompok immunoglobulin molekul adhesi yang merupakan reseptor protein dan terdapat pada permukaan sel. Mediator VCAM-1 berperan dalam pengikatan antara sel dengan sel atau sel dengan jaringan ikat, selain itu juga mempunyai kontribusi dalam proses recruitment monosit dan pembentukan fatty streak selama proses awal aterogenesis, ${ }^{14}$ karena sebagian dari protein VCAM-1 dilepaskan ke dalam proses aterosklerosis dan dapat dipakai untuk menilai derajat aterosklerosis tersebut. ${ }^{15}$

Penelitian ini membandingkan kadar sVCAM pada setiap kelompok subjek penelitian. Analisis statistik dengan menggunakan ANOVA menunjukkan perbedaan yang signifikan antara kedua kelompok tersebut $(\mathrm{F}=22,43 ; \mathrm{p}<0,01)$, rerata konsentrasi sVCAM pada SN kambuh sering 871,0 ng/ml (4611777 ng/ml), SN kambuh jarang 1038,3 ng/ml (479$1574 \mathrm{ng} / \mathrm{ml}$ ) dan kelompok kontrol 691,1(436-942 $\mathrm{ng} / \mathrm{ml})$. Hasil tersebut menunjukkan bahwa nilai sVCAM pada kelompok SN kambuh lebih tinggi dibandingkan dengan kelompok kontrol, serta pada kelompok SN kambuh jarang lebih tinggi dibandingkan dengan SN kambuh sering.

Konsentrasi sVCAM pada kelompok kontrol cukup tinggi, hasil ini sama dengan penelitian yang dilakukan oleh Nash dkk. ${ }^{12}$ Penelitian tersebut dilakukan pada 238 anak sehat usia $(9,5-15,5)$ tahun, dengan hasil rata-rata kadar sVCAM-1 $750 \mathrm{ng} / \mathrm{ml}$ dan $625 \mathrm{ng} / \mathrm{ml}$ yang berhubungan dengan umur (pada umur lebih tua didapatkan kadar sVCAM lebih rendah). Penelitian tersebut juga memperlihatkan nilai sVCAM-1 pada anak sehat usia 5 tahun dua kali lebih tinggi bila dibandingkan dengan dewasa. ${ }^{12}$

Beberapa penelitian lainnya melaporkan bahwa VCAM-1 memegang peran yang penting pada proses aterosklerosis yaitu 1) peningkatan VCAM-1 pada beberapa penelitian berhubungan dengan timbul plak aterosclerosis pada manusia 2) hubungan antara makrofag dengan VCAM-1 pada pembuluh darah yang mengalami aterosklerosis 3) Lisofosfatidil kolin sebagai komponen lipoprotein aterogenik memicu timbulnya VCAM-1 dan meningkatkan monosit dan pembentukan endotel pada sel kultur 4) LDL teroksidasi merupakan bagian yang penting dari hubungan antara VCAM-1 dengan sitokin. ${ }^{14}$ Beberapa 
laporan tersebut memperlihatkan betapa pentingnya peran VCAM-1 dalam proses terjadinya aterosklerosis termasuk kaitannya dengan kompoen profil lemak. ${ }^{14}$

Hasil analisa regresi linier nilai adjusted $R^{2}$ sebesar $8,9 \%$, berarti jenis sindrom nefrotik hanya mempunyai kontribusi yang kecil terhadap peningkatan kadar sVCAM-1 yaitu sebesar 8,9\%. Nilai ini tidak begitu besar tetapi tidak dapat diabaikan karena memberikan satu bahan pemikiran baru dalam kaitannya dengan pengelolaan pasien SN yang disertai hiperlipidemia, apalagi bila hiperlipidemia berlangsung berulangulang, atau bahkan menetap seperti pada anak dengan SN kambuh sering.

\section{Kesimpulan}

Terdapat perbedaan bermakna kadar sVCAM-1 pada SN kambuh sering, SN kambuh jarang dan kelompok kontrol. Kadar sVCAM-1 pada kelompok SN kambuh lebih tinggi dari kelompok kontrol, sedangkan di antara kelompok SN kambuh, kadar sVCAM-1 pada SN kambuh jarang lebih tinggi dari SN kambuh sering. Jenis $S N$ memberikan kontribusi yang rendah terhadap peningkatan kadar sVCAM-1, walaupun prognosis SN kambuh sering akan menjadi lebih buruk dibandingkan dengan SN kambuh jarang akibat adanya faktor risiko proses aterosklerosis yang berulang-ulang.

\section{Daftar Pustaka}

1. Haycock G. The child with idiopathic nephrotic syndrome. Dalam: Webb NJ, Postlethwaite RJ, penyunting. Clinical pediatric nephrology. Edisi ke-3. New York: Oxford University Press; 2003.h.342-66.

2. Roth KS, Amaker BH, Chan JCM. Nephrotic syndrome: pathogenesis and management. Pediatr Rev. 2002: 23:237-47.

3. Davis ID, Avner ED. Glomerular disease. Dalam: Behrman RE, Kliegman RM, Jenson HB, penyunting. Nelson Textbook of Pediatrics. Edisi ke-17. Philadelphia: WB Saunders; 2004. h. 1731-4.
4. Orth SR, Ritz E. The nephrotic syndrome. N Engl J Med 1998; 338:1202-11.

5. Kelsch RC, Sedman AB. Nephrotic syndrome. Pediatr Rev. 1993;14:30-9.

6. Ponco E. Hubungan kadar kolesterol total darah dengan frekuensi relaps pada anak dengan sindrom nefrotik di Bagian/SMF Ilmu Kesehatan Anak FKUP/RS Hasan Sadikin 1995-1999. Thesis. Bandung: Padjadjaran University; 1999.

7. Ordonez JD, Hiatt R, Killebrew E, Fireman B. The risk of coronary artery disease among patients with the nephritic syndrome (abstract). Kidney Int. 1990;37:234A.

8. Keane WF. Lipid and the kidney. Kidney Int. 1994; 46:910-20.

9. Peter K, Nawroth P, Conradt C. Circulating vascular cell adhesion molecule- 1 correlate with the extent of human atherosclerosis in contrast to circulating intercellular adhesion molecule-1, E-selectin, P-selectin, and thrombomodulin. Arterioscler Thromb Vasc Biol. 1997; 17:505-12.

10. Samuelsson B. Inflamation. Dalam: Tizard IR, penyunting. Immunology an introduction. Edisi ke-4. Philadelphia: Saunders; 1994.h.432-51.

11. Wheeler DC. Lipid abnormalities in the nephritic syndrome: the theurapetic role of statins. J Nephrol. 2001;14 (Suppl 4):70-5

12. Nash MC, Wade AM, Shah V, Dillon MJ. Normal levels of soluble E-selectin, soluble intracellular adhesion molecule-1 (sICAM-1) and soluble vascular cell adhesion molecule-1 (sVCAM-1) decrease with age. Clin Exp Immunol. 1996;103:167-70.

13. Silva JMP. Premature acute myocardial infarction in a child with nephritic syndrome. Pediatr Nephrol. 2002;17:169-72

14. Ross R. Atherogenesis. Dalam: Gallin JL, Snyderman $\mathrm{R}$, penyunyting. Inflammation, basic principles and clinical correlates. Edisi ke-3. Philadelphia: Lippincott Williams \& Wilkins; 1999. h.1083-95.

15. Fruebis J. Gonzales V. Silvestre M, Pallinski W. Effect of probucol treatment on gene expression of VCAM-1, MCP-1, M-CSF in the aortic wall of LDL-receptor-deficient rabbits during early atherogenesis. Arterioscler Thromb Vasc Biol. 1997;17:1289-302. 